\title{
Modal Sosial Perempuan dalam Peran Penguatan Ekonomi Keluarga
}

Oleh

\author{
Dewi Cahyani Puspitasari ${ }^{1}$
}

\begin{abstract}
Abstrak
Eksistensi perempuan memiliki peran penting baik pada ranah domestik (keluarga) dan publik (masyarakat). Dalam perannya mengelola keuangan keluarga baik dari hasil nafkah suami maupun kerja produktifnya menjadikan perempuan sadar akan posisinya menjaga keberlangsungan ekonomi keluarga. Perempuan mampu mendayagunakan sumber ekonomi melalui pemanfaatan stok modal sosial yang dimilikinya berupa jejaring sosial dalam lingkungan sosial untuk mempertahankan bahkan meningkatkan ekonomi keluarga. Dari pengalaman pendampingan ekonomi perempuan usaha mikro, penulis mencoba mengkonseptualisasikan dalam kerangka fungsi dan peran modal sosial untuk penguatan ekonomi keluarga. Dengan demikian, pilihan saluran penghidupan perempuan dan keluarganya melalui pemanfaatan modal sosial menjadi peluang strategis dan produktif untuk menjaga daya tahan ekonomi keluarga.
\end{abstract}

Kata Kunci: perempuan, modal sosial, ekonomi keluarga.

\begin{abstract}
The existence of female has an important role both on domestic (family) and public society). In that role manage family finance either revenue from her husband or her productive work make women aware of hers position maintain sustainability of economic family. Women are capable to leverage existing economic resources through utilization of social capital stock owned, in the form of social network in social environment to maintain even increasing economic family. From experiences assistance women micro entreprises, writer try to conceptualize within framework of the function and role of social capital for strengthening economic family. Thus, the choice of livelihood and family channels through utilization of social capital into productive and strategic opportunities to keep durability of economic family
\end{abstract}

Keywords: woman, social capital, economic family.

\section{A. Pendahuluan}

Pembangunan nasional dalam dinamika wacana dan implementasinya menuai beragam pendapat dan hasil di masyarakat. Bila ditinjau dari indikator ekonomi makro, berbagai laporan dan studi menunjukkan prospek dan kinerja pembangunan ekonomi Indonesia. Faktanya justru memunculkan kondisi berbeda yaitu masih adanya data kemiskinan, pengangguran, kriminalitas serta masalah kesenjangan di berbagai daerah. Dengan kata lain, proses pembangunan yang secara ideal

\footnotetext{
${ }^{1}$ Dewi Cahyani Puspitasari menyelesaikan studi S1 dan S2 Sosiologi di Universitas Gadjah Mada. Staff pengajar di Jurusan Sosiologi Fisipol UGM.
} 
Jurnal Pemikiran Sosiologi Volume 1 No. 2, 2012

Modal Sosial Perempuan dalam Peran Penguatan Ekonomi Keluarga

Dewi Cahyani Puspitasari

diharapkan dapat membawa arah kemajuan bagi perubahan dan peningkatan kesejahteraan masyarakat justru muncul dengan wajah paradoks pembangunan. Indikasi diskoneksitas antara capaian pembangunan ekonomi makro dengan kualitas pemerataan pembangunan di Indonesia inilah yang kemudian salah satunya berimplikasi pada kondisi ekonomi keluarga sebagai entitas terkecil masyarakat.

Keluarga dalam pembangunan memiliki porsi dan kontribusi penting yaitu sebagai institusi sosial primer yang memberikan sosialisasi awal berupa pendidikan nilai dan norma pada anggota keluarga. Selain itu melalui keluarga inilah pondasi awal membentuk kualitas sumber daya manusia dimana hal ini telah menjadi indikator ketercapaian pembangunan yaitu Indeks Pembangunan Manusia (IPM). Dalam hal ekonomi, keluarga menjadi salah satu penyumbang tenaga kerja produktif yang masuk ke dalam pasar kerja nasional. Karena itu, beberapa kebijakan pembangunan nasional menjadikan keluarga sebagai sasaran pencapaian programnya yang melibatkan unsur anggota keluarga. Salah satu unsur keluarga yang berkontribusi dalam hal ekonomi adalah perempuan. Hal ini seperti yang diutarakan Endang (2007) bahwa pada dasarnya, perempuan mempunyai fungsi utama yang sangat berkaitan dengan kedudukan dan perannya yakni fungsi produksi dan fungsi reproduksi. Fungsi produksi berkaitan dengan fungsi ekonomis yaitu semakin tinggi tingkat pendidikan perempuan memungkinkan mereka secara tidak langsung dan langsung menjadi pelaku pembangunan sesuai minat dan kemampuannya sebagai faktor produksi. Sementara, fungsi reproduksi baik kodrati (melahirkan, menyusui) maupun non kodrati (mendidik dan mengasuh anak) dapat dikategorikan sebagai aktivitas mengurus rumah tangga atau dalam istilah BPS sebagai bukan angkatan kerja.

Dalam tulisan ini mengenai perempuan, modal sosial dan pemberdayaan ekonomi keluarga adalah isu penting yang memotret perempuan dari kelompok berpendapatan kecil dengan profesi usaha mikro mampu mengatasi kesulitan finansial keluarga. Perempuan ini mampu memanfaatkan peluang berupa jejaring sosial di lingkungan tempat tinggal mereka berupa ragam pertemuan sosial sampai pada bentuk organisasi dan kegiatan sosial untuk kepentingan pemenuhan ekonomi keluarga. Hal ini dibahas mengingat peran ganda perempuan baik di ranah domestik (rumah tangga) dan publik (masyarakat) yang mampu diemban secara aktif dan strategis untuk mengatasi keterbatasan ekonomi keluarga.

\section{B. Peran Perempuan dan Pemberdayaan Ekonomi Keluarga}

Rendahnya status ekonomi perempuan di Indonesia salah satunya karena lemahnya perempuan dalam mengakses sumber daya di keluarga, masyarakat ataupun negara. Upaya pengurangan kemiskinan dan ketidakadilan yang dialami perempuan akan berimplikasi pada kesejahteraan dan kelangsungan hidup keluarga dan masyarakat. Histori ini dapat terlihat saat Indonesia mengalami krisis ekonomi yang berdampak buruk pada pendapatan keluarga sehingga meningkatkan jumlah kemiskinan dan pengangguran. Kondisi ini dipandang Izza (2009:75) akan berpengaruh semakin buruk bila para pembuat 
Jurnal Pemikiran Sosiologi Volume 1 No. 2, 2012

Modal Sosial Perempuan dalam Peran Penguatan Ekonomi Keluarga

Dewi Cahyani Puspitasari

kebijakan dan program mengabaikan perbedaan kondisi dan kemampuan dari berbagai elemen masyarakat termasuk di dalamnya laki-laki dan perempuan. Selain itu menurut Izza (2009:74) bahwa perempuan mempunyai persepsi yang lebih beragam dibandingkan laki-laki dalam kesejahteraan atau kemiskinan yaitu disamping aspek yang berhubungan dengan akses pendapatan, kepemilikan aset, kualitas kesehatan, pangan serta peluang, juga mencermati hal-hal berkaitan dengan kehidupan keluarga seperti keharmonisan keluarga, rasa aman, ada tidaknya hubungan dengan rentenir, gaya hidup, kemampuan membantu orang tua dan orang lain serta hubungan sosial dengan tetangga. Dari ragam kondisi tersebut pada akhirnya direspon oleh pemerintah salah satunya melalui kebijakan pemberdayaan perempuan yang mengarah pada peningkatan ekonomi keluarga termasuk keikutsertaan Indonesia dalam menyukseskan Deklarasi Millenium Development Goals (MDG).

Program pemberdayaan ekonomi keluarga menjadi bagian dari skema penanggulangan kemiskinan dan peningkatan kesejahteraan masyarakat. Program tersebut ada yang bersifat bantuan (karitatif) dan produktif. Beberapa program (Izza,2009:126-132) yaitu sebelum krisis meliputi program IDT (Inpres Desa Tertinggal) serta Takesra-Kukesra, saat krisis berupa JPS (Jaring Pengaman Sosial), PDM DKE (Pemberdayaan Masyarakat Dalam Mengatasi Dampak Krisis), Revitalisasi Posyandu melalui PKK dan Kartu Sehat dan program kompensasi BBM seperti Raskin (beras untuk rakyat miskin), SLT (subsidi langsung tunai), BOS (bantuan operasional sekolah), Jamkesmas (jaminan kesehatan masyarakat), PKH (program keluarga harapan), PNPM dan beragam bantuan sosial lainnya. Ketercapaian program-program tersebut menuai hasil atau output berbeda. Bila orientasi program tersebut pada aspek pemberdayaan, menurut Alwi (dalam Izza,2009:171) pemberdayaan harus diintegrasikan melalui dimensi proses yang benar yaitu dengan menempatkan masyarakat secara langsung didorong pada posisi 'terlibat'. Bila pemberdayaan tidak berjalan dengan lancar maka akan menimbulkan kesenjangan baik ekonomi maupun sosial.

Mencermati pemberdayaan perempuan menurut Linda (dalam Herliawati,2009:13) yaitu: merupakan proses perubahan dimana individu atau kelompok dengan sedikit atau tanpa kekuasaan memperoleh kekuasaan dan kemampuan membuat pilihan yang dapat memengaruhi kehidupan mereka. Struktur kekuasaan yang memilikinya, sumber daya apa dan bagaimana memanfaatkannya secara langsung memengaruhi pilihan perempuan untuk dapat memanfaatkannya dalam kehidupan mereka. Sementara Gita Sen (dalam Herliawati,2009:13) menyatakan pemberdayaan merupakan upaya mengubah kekuasaan yang memaksa pilihan perempuan, otonomi dan memengaruhi kesehatan serta kesejahteraan. Dari kedua pendapat tersebut, pemberdayaan perempuan bermuara dari konsep pengarusutamaan gender, kesetaraan gender dan keadilan. Pada akhirnya, pola-pola pemberdayaan perempuan memerlukan perubahan secara mendasar agar tidak melemahkan posisi dan otonomi perempuan. Oleh karena itu, perlu pendekatan strategis yang mampu menjamin dan mengarahkan kegiatan pemberdayaan perempuan pada usaha agar perempuan tetap berada dalam dua ranah yaitu domestik (rumah tangga) dan publik (masyarakat).

Pilihan strategi pemberdayaan masyarakat dalam penanggulangan kemiskinan dengan sasaran perempuan dan keluarga salah satunya adalah peningkatan partisipasi dalam kegiatan ekonomi berbasis potensi dan sumber daya lokal. Dalam hal 
Jurnal Pemikiran Sosiologi Volume 1 No. 2, 2012

Modal Sosial Perempuan dalam Peran Penguatan Ekonomi Keluarga

Dewi Cahyani Puspitasari

pencapaian keswadayaan dan kemandirian ekonomi

melalui pemberdayaan ekonomi menurut Izza (2009:172) dapat diartikan sebagai serangkaian kegiatan untuk meningkatkan aset dan kemampuan masyarakat miskin agar mau dan mampu mengakses berbagai sumber daya, permodalan, teknologi dan pasar dengan pendekatan pendampingan, peningkatan kapasitas, pelayanan dan pembelaan menuju kemandirian masyarakat. Dari proses ini diharapkan tujuan pemberdayan ekonomi berupa peningkatan pendapatan dan kesejahteraan bagi keluarga dilakukan dengan meningkatkan usaha yang ada maupun menciptakan kesempatan kerja baru serta meningkatkan daya tawar mereka melalui pendampingan partisipatif dan berkelanjutan. Selain itu, menurut Endang (2007) bahwa pemberdayaan perempuan dapat mengacu pada fungsi SDM dari perempuan itu sendiri di dalam rumah tangga. Perempuan bisa sebagai anak, pasangan suami (istri), ibu dari anak-anaknya, nenek dan manajer rumah tangga. Sosok perempuan dalam rumah tangga selalu siap mengorbankan waktu, tenaga, pikiran termasuk harta yang dimiliki untuk kesejahteraan keluarga, sementara perempuan di luar rumah dapat sebagai sosok pekerja. Kondisi tersebut dapat diilustrasikan sebagai berikut: 
Gambar 1. Fungsi SDM Perempuan
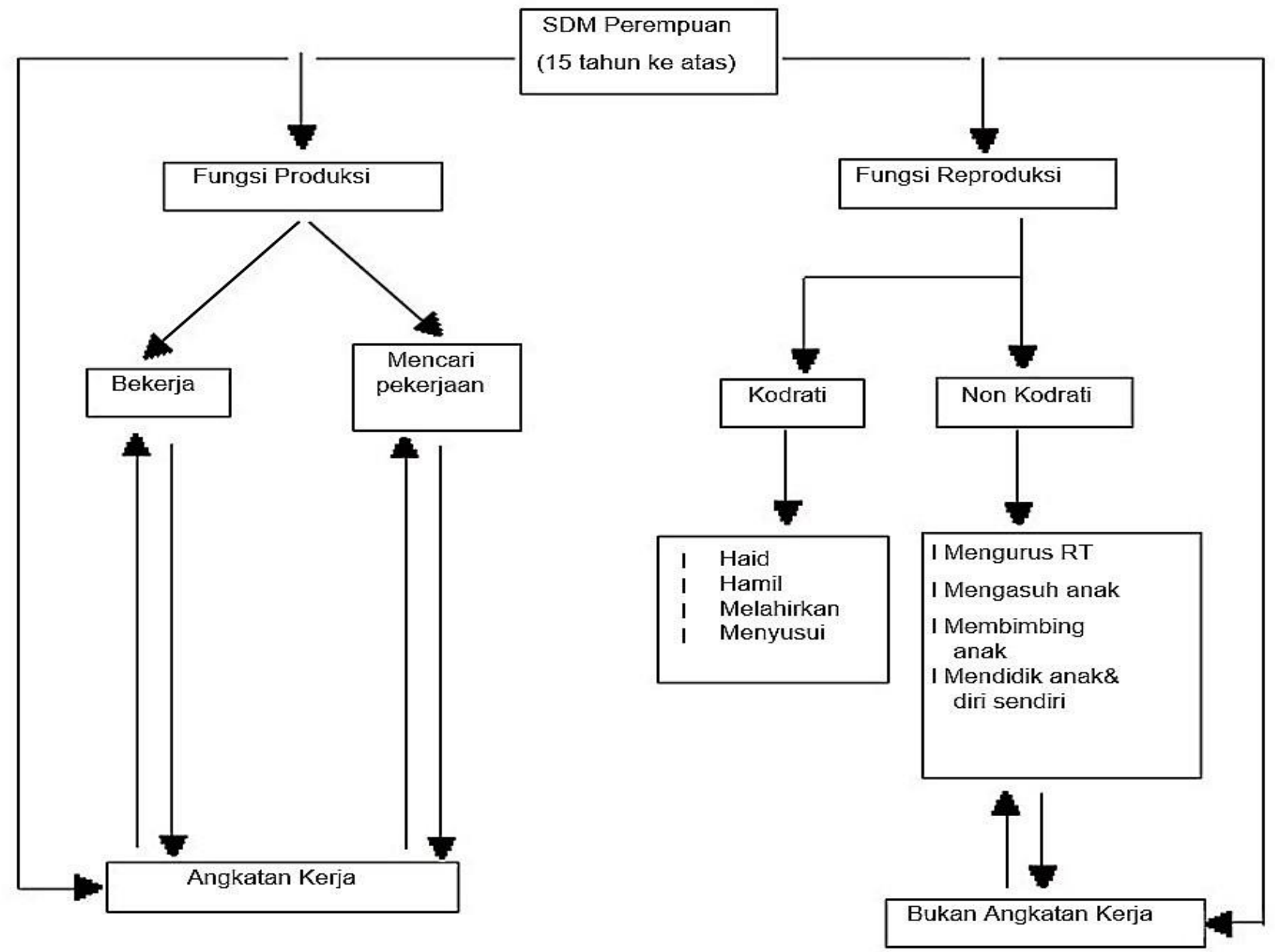

Sumber: Endang (2007:150)

Mengacu pembahasan tersebut, pengalaman pendampingan pada perempuan usaha mikro yang dilakukan penulis berafiliasi dengan salah satu LSM yang konsen pada pemberdayaan perempuan usaha mikro di wilayah Bantul menjadi contoh kasus implementasi strategi pemberdayaan ekonomi keluarga melalui peningkatan peran perempuan usaha mikro. Kendala yang dihadapi oleh perempuan usaha mikro ada pada tataran akses permodalan, hambatan pengembangan jaringan usaha selain juga minimnya edukasi perempuan usaha mikro dalam pengelolaan keuangan keluarga. Karenanya menjadi lazim bagi perempuan usaha mikro mengandalkan kegiatan simpan pinjam melalui pertemuan arisan, bergabung dalam koperasi sampai ada yang masih kontak dengan rentenir. Kondisi ini ditambah fakta geografis dimana domisili perempuan usaha mikro mayoritas di wilayah pedesaan dengan ketersediaan kendaraan pribadimyang minimal menjadikan mobilitas perempuan dalam menjalankan usahanya masih berada sekitar wilayah lokal setempat. Padahal bila ditelisik lebih lanjut, potensi dan peluang stok modal sosial perempuan usaha mampu menjadi alternatif strategi yang produktif meningkatkan ekonomi keluarga. 
Jurnal Pemikiran Sosiologi Volume 1 No. 2, 2012

Modal Sosial Perempuan dalam Peran Penguatan Ekonomi Keluarga

Dewi Cahyani Puspitasari

\section{Potret Modal Sosial Perempuan: Kasus Perempuan Usaha Mikro}

Dalam konteks perempuan sebagai modal sosial dapat mempertimbangkan simpulan sementara bahwa elemen utama modal sosial terdiri dari norms, reciprocity, trust, dan network maka sebenarnya hal tersebut secara historis bukan merupakan fenomena baru dan asing bagi masyarakat di Indonesia karena hal tersebut telah berakar kuat dan terinstitusikan dalam kehidupan sehari-hari masyarakat. Modal sosial merupakan pilar yang mewujudkan spirit kebersamaan dalam mencapai suatu tujuan (Dewi,2010). Perempuan usaha mikro di wilayah Bantul yang menjadi pencermatan penulis memiliki kapasitas berupa entitas spirit dengan daya tahan dan daya juangnya dengan sifat dinamis dan kreatifnya mampu mengatasi beragam problem ekonomi keluarga. Bila diidentifikasi, maka komponen modal sosial perempuan usaha mikro dapat diilustrasikan sebagai berikut:

Dari skema tersebut dapat ditunjukkan bahwa perempuan usaha mikro memiliki stok modal sosial berupa nilai budaya gotong royong atau saling membantu dengan motif percaya (trust), mekanisme yang terwujud melalui kerjasama dan sinergi dalam beragam aktivitas forum pertemuan warga dan pada akhirnya dapat menjadi bentukan institusi dari entitas perempuan usaha mikro berupa asosiasi usaha serta koperasi.

Kesediaan perempuan usaha mikro untuk melibatkan diri dalam berbagai aktivitas sosial dari komunitas atau organisasi sosial tersebut menjadi peluang yang awalnya tidak pernah dikalkulasi secara ekonomi. Dengan kata lain, implikasi ekonomi dari partisipasi aktif perempuan usaha mikro baru dirasakan dampaknya setelah relasi sosial yang semakin intensif ditambah dengan kegiatan produktif. Hal ini seperti yang dilakukan dalam kegiatan pendampingan oleh salah satu LSM perempuan usaha mikro di wilayah Bantul tanpa

\section{Gambar 2. Komponen Modal Sosial Perempuan Usaha Mikro}

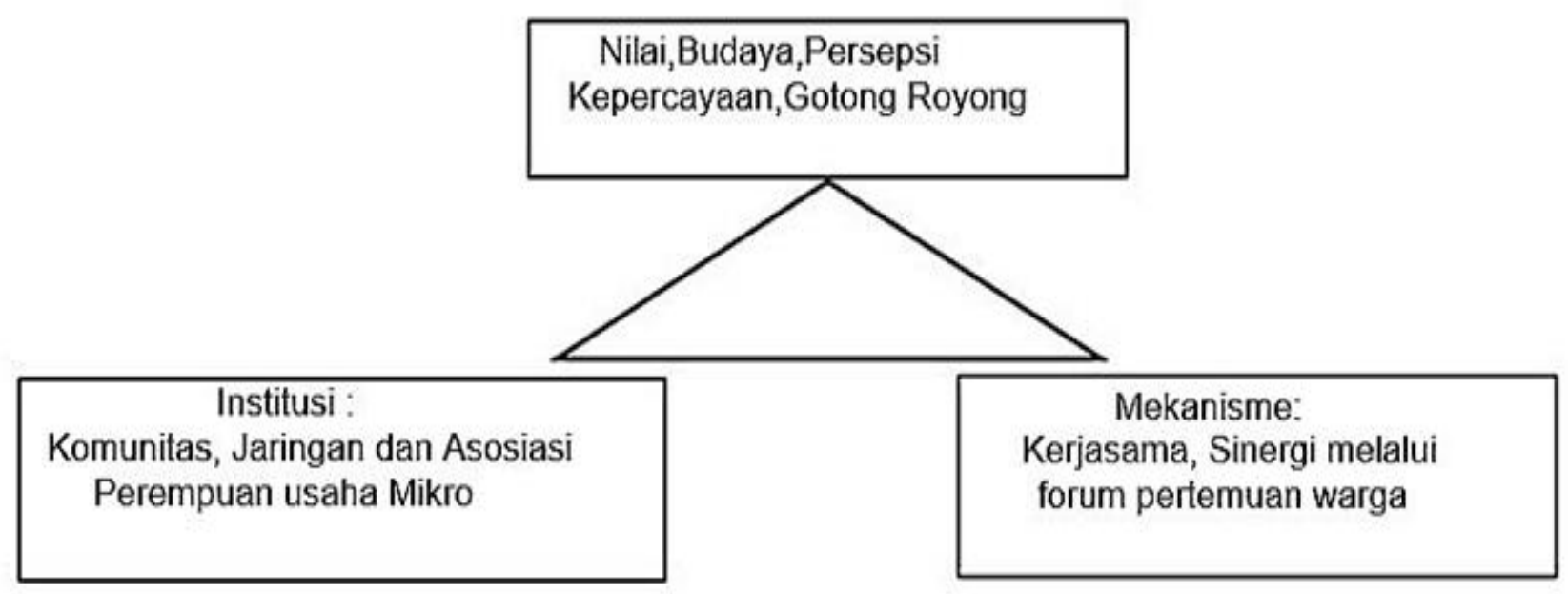

Sumber : Adaptasi Mefi Hermawanti dan Hesti Rinandari (2003:8). 
Jurnal Pemikiran Sosiologi Volume 1 No. 2, 2012

Modal Sosial Perempuan dalam Peran Penguatan Ekonomi Keluarga

Dewi Cahyani Puspitasari

harus membentuk kelembagaan sosial baru tetapi masuk dalam forum pertemuan warga (perempuan usaha mikro). Kegiatan arisan yang awalnya bersifat kumpul-kumpul (berkumpul) beralih menjadi sarana ngangsu kawruh (media belajar bersama yang disebut Temu Suruh). Introduksi dan edukasi pengelolaan ekonomi keluarga termasuk pengelolaan usaha menjadi muatan utamanya ditambah dengan aktivitas simpan pinjam dengan model tanggung renteng (pinjaman kelompok). Forum pertemuan tersebut menjadi semakin dinamis dan produktif karena mampu menjawab kebutuhan perempuan usaha mikro khususnya dalam pengelolaan usaha yang berimplikasi pada ekonomi keluarga. Dengan demikian, perempuan usaha mikro menjadikan ruang jejaring sosial tersebut sebagai strategi bertahan ketika suatu saat usahanya sedang dilanda masalah. Hal ini dikarenakan mekanisme tanggung renteng dengan basis saling membantu saat ada anggota yang membutuhkan menjadi solusi tercepat atas masalah yang dihadapi perempuan usaha mikro.

Partisipasi aktif perempuan tersebut yang kemudian memberikan kontribusi bagi peningkatan ekonomi keluarga sekaligus penguatan kapasitas melalui kegiatan pendampingan. $\mathrm{Hal}$ ini bila dikonseptualisasikan dengan modal sosial dapat dijelaskan sebagai berikut:

\section{Dimensi Nilai dan Kultur}

Masyarakat yang terdiri dari individu-individu merupakan makhluk sosial dengan ciri saling membutuhkan satu sama lain dalam kehidupannya. Oleh karenanya terdapat kecenderungan untuk saling bekerja sama dan saling berinteraksi termasuk pada saat kondisi bencana dimana semua orang membutuhkan untuk bertahan hidup/melangsungkan kehidupannya. Dalam berinteraksi bukan tanpa suatu nilai dan norma dimana menurut Fukuyama (dalam Dewi,2010) menjelaskan bahwa"Social capital can be defined simply as the existence of a certain set of informal values or norms shared among members of a group that permit cooperation among them. (Modal sosial adalah serangkaian nilai-nilai atau norma-norma informal yang dimiliki bersama di antara para anggota suatu kelompok masyarakat yang memungkinkan terjalinnya kerjasama diantara mereka). Pendapat ini senada dengan penjelasan Hasbullah (2006:14) bahwa nilai sebagai sesuatu ide yang telah turun temurun dianggap benar dan penting oleh anggota kelompok masyarakat. Karenanya, dominasi ide tertentu dalam masyarakat akan membentuk dan mempengaruhi aturan-aturan bertindak masyarakatnya (the rules of conducts) dan aturan-aturan bertingkah laku (the rules of behavour) yang bersama-sama membentuk polapola kultural (cultural pattern).

Dari penjelasan di atas dapat dikontekskan dengan aktivitas pendampingan pada perempuan usaha mikro yang mendasarkan pada nilai dan norma masyarakat sebagai bagian dari komponen modal sosial. Pendampingan yang mengadaptasi model kelompok memuat beberapa konsensus bersama atau disebut 'Prinsip Anggota' yaitu:

1. Bertekad meningkatkan kualitas hidup;

2. Menjalankan usaha untuk ibadah;

3. Disiplin dan dapat dipercaya;

4. Bersungguh-sungguh dan cerdas dalam bekerja, dan;

5. Saling membantu anggota bila mereka berada dalam kesulitan 
Jurnal Pemikiran Sosiologi Volume 1 No. 2, 2012

Modal Sosial Perempuan dalam Peran Penguatan Ekonomi Keluarga

Dewi Cahyani Puspitasari

Penjelasan tersebut memberi pemahaman bahwa basis nilai dan kultur yang dibangun oleh perempuan usaha mikro dalam kegiatan peningkatan ekonomi keluarga merupakan implikasi dari kesediaan perempuan untuk mengkonsolidasikan diri dengan pihak di luar dirinya termasuk pendamping LSM. Selain itu, dimensi nilai dan kultur inilah yang kemudian menjadi 'perekat' interaksi sosial diantara perempuan usaha mikro.

\section{Dimensi Trust, Reciprocity dan Partisipasi}

Pembahasan ini lebih melihat pada sisi mekanisme relasi yang terbentuk antar aktor yaitu perempuan usaha mikro dengan pendamping LSM terkait dengan kegiatan peningkatan ekonomi keluarga. Bila merujuk pemahaman mengenai modal sosial dari aspek reciprocity ini menurut Hasbullah (2006:10) modal sosial senantiasa diwarnai oleh kecenderungan saling tukar kebaikan antar individu dalam suatu kelompok atau antar kelompok itu sendiri. Pola pertukaran atau resiprositas ini bukanlah sesuatu yang dilakukan secara resiprokal seketika melainkan suatu kombinasi jangka pendek dan jangka panjang dalam nuansa altruism yaitu semangat untuk membantu dan mementingkan kepentingan orang lain. Meski kemudian konsep reciprocity tidak akan dapat berjalan dalam relasi antar individu atau antarkelompok dalam komunitas ketika tidak ada rasa percaya (distrust).

Selanjutnya, penjelasan mengenai dimensi trust ini seperti pendapat Putnam (dalam Hasbullah, 2006:11) yaitu rasa percaya (trust) merupakan suatu bentuk keinginan untuk mengambil resiko dalam hubungan sosialnya yang didasari oleh perasaan yakin bahwa yang lain akan melakukan sesuatu seperti yang diharapkan dan senantiasa bertindak dalam suatu pola tindakan saling mendukung. Inilah yang kemudian akan menjadi modal sosial lanjutan untuk membangun suatu jaringan diantara kelompok atau komunitas untuk melakukan kerjasama yang saling menguntungkan. Hal ini sesuai pendapat Fukuyama (dalam Dewi,2010) bahwa jaringan sebagai modal sosial merupakan hubungan moral kepercayaan yaitu jaringan adalah sekelompok agen-agen individual yang berbagi norma-norma atau nilai-nilai informal melampaui nilai-nilai atau norma-norma yang penting untuk transaksi-transaksi pasar biasa. Pada pembahasan ini memberikan pemahaman bahwa modal sosial tidak dibangun oleh satu individu melainkan terletak pada kecenderungan yang tumbuh dalam suatu kelompok (komunitas).

Penjelasan tersebut bila dikontekskan dengan contoh peran perempuan usaha mikro dalam kelompok dampingan Temu Suruh menunjukkan bahwa kekuatan perempuan usaha mikro ada pada aspek saling percaya dan membutuhkan terhadap kapasitas yang dimiliki oleh masing-masing perempuan. Dari sinilah perempuan usaha mikro dapat saling bertukar informasi untuk menguatkan peran masing-masing dalam melakukan akitivitas peningkatan ekonomi keluarga. Pada akhirnya perempuan usaha mikro mampu berpartisipasi aktif di lingkungan masyarakatnya yang diharapkan kondisi ini secara jangka panjang dapat terpelihara dengan baik.

Selanjutnya, potret modal sosial perempuan usaha mikro dapat dilihat dalam bentukan model modal sosial yang berbeda dari aktivitas pemenuhan ekonomi keluarga. Model modal sosial perempuan usaha mikro diadopsi dari pendapat Woolcock (dalam Mefi, 2003) yang membedakan 3 (tiga) tipe modal sosial yaitu : (1) Social Bounding,berupa 


\section{Gambar 3. Model Modal Sosial Perempuan Usaha Mikro}

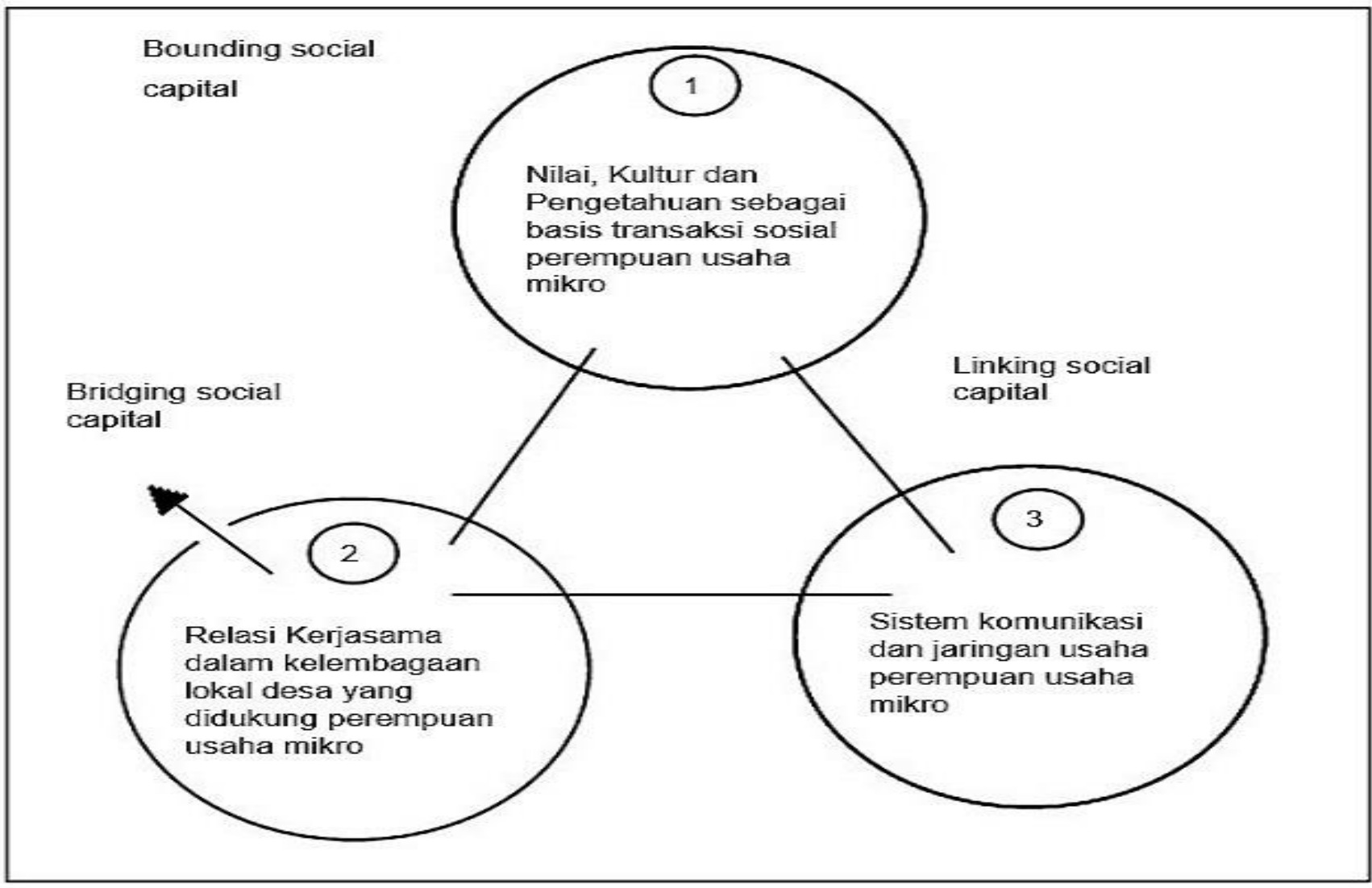

Sumber: Adaptasi dari Dewi,2010.

nilai,kultur, persepsi dan tradisi (custom), yaitu modal sosial dengan karakteristik ikatan yang kuat dalam suatu sistem kemasyarakatan dimana masih berlakunya sistem kekerabatan yang mewujudkan rasa simpati, berkewajiban, percaya resiprositas, dan pengakuan timbal balik nilai kebudayaan yang dipercaya; (2) Social bridging, berupa institusi maupun mekanisme yang merupakan ikatan sosial yang timbul sebagai reaksi atas berbagai macam karakteristik kelompoknya; (3) Social linking, berupa hubungan/jaringan sosial dengan adanya hubungan di antara beberapa level dari kekuatan sosial maupun status sosial yang ada dalam masyarakat. Dengan demikian, relasi yang terjalin dalam kegiatan program dan aktivitas perempuan usaha mikro dapat diilustrasikan sebagai berikut:
Dari gambar diatas menunjukkan bahwa ketiga level modal sosial di atas memberi pengertian bahwa modal sosial dapat memberi kontribusi bagi terjadinya integrasi sosial sekaligus mengatasi problem seputar pengelolaan usaha maupun ekonomi keluarga perempuan usaha mikro. Dalam hal ini bila mencermati mekanisme relasi diantara aktor yang melibatkan perempuan usaha mikro dengan pihak pendamping (LSM) terkait program pendampingan melalui simpan pinjam jelas tergantung pada kapasitas yang ada dalam kelompok masyarakat. Kapasitas yang dimaksud adalah untuk membangun sejumlah asosiasi berikut jaringannya termasuk membangun basis nilai dan trust untuk kemudian saling bekerjasama sebagai unsur resiprositas. Selain itu terletak pula pada kemampuan perempuan 
Jurnal Pemikiran Sosiologi Volume 1 No. 2, 2012

Modal Sosial Perempuan dalam Peran Penguatan Ekonomi Keluarga

Dewi Cahyani Puspitasari

usaha mikro untuk melibatkan diri dalam suatu jaringan hubungan sosial kemasyarakatan.

\section{Penguatan Peran Modal Sosial Perempuan dalam Peningkatan Ekonomi Keluarga}

Perkembangan pembangunan dengan memanfaatkan modal sosial telah ditunjukkan hasil studi di berbagai negara (Dasgupta,200o) bahwa modal sosial yang kuat akan merangsang pertumbuhan berbagai sektor ekonomi. Hal ini didukung adanya tingkat rasa percaya (trust) yang tinggi dengan kerekatan hubungan sosial dan kapasitas membangun jaringan yang luas tumbuh diantara sesama pelaku ekonomi. Sebaran spektrum modal sosial inilah yang kemudian mampu memberi pengaruh dan menggerakkan perkembangan antar sektor ekonomi. Konteks makro pemanfaatan modal sosial ini bila didekatkan dengan pemberdayaan ekonomi keluarga menjadi relevan karena ujung tombak dari kesejahteraan masyarakat diawali dari kesejahteraan keluarga.

Perempuan memiliki peran strategis dan produktif dalam peningkatan ekonomi keluarga. Keluwesan perempuan dalam membina relasi sosial dengan lingkungan sosialnya menjadikan peluang terbukanya akses sumber daya ekonomi. Hanya saja, keterlibatan perempuan dalam kegiatan ekonomi seringkali kurang dilengkapi dengan pengetahuan dan keterampilan atau problem teknis usaha sehingga membuat tidak mampu bersaing dalam kompetisi pasar. Selain itu problem struktural berupa kebijakan pemerintah yang berkaitan dengan pengembangan usaha masih belum banyak berpihak pada kepentingan perempuan. Kondisi ini yang dialami perempuan usaha mikro sehingga rentan bila berhadapan dengan realitas pasar kompetitif yang dapat berimplikasi pada ekonomi keluarganya.

Intensifikasi pemanfaatan modal sosial yang dikoneksikan dengan pemberdayaan ekonomi keluarga menjadi solusi untuk memunculkan tindakan kolektif yang berorientasi pada pemunculan aktivitas ekonomi produktif. Modal sosial yang mewujud dalam bentuk kohesifitas sosial, semangat gotong royong, tolong menolong, rasa dan semangat untuk saling memberi (reciprocity), trust (rasa saling percaya) dan jaringan sosial (social networking) menjadi energi penopang keberlanjutan usaha dan bertahannya ekonomi keluarga. Kondisi ini diamati dari aktivitas perempuan usaha mikro yang dapat dibedakan sebagai berikut: (a) aktivitas bermotif ekonomi yaitu aktivitas terkait dengan upaya perempuan usaha mikro mendapatkan pendapatan untuk memenuhi kebutuhan sehari-hari keluarga melalui simpan pinjam; dan (b) aktivitas non-ekonomi yaitu aktivitas yang dilakukan dengan tujuan menguatkan ikatan solidaritas sesama perempuan usaha mikro, misal aktivitas religi maupun sosial budaya (pengajian, arisan maupun budaya rewang). Terkadang hubungan di antara kedua dimensi ini menjadi 'kabur' karena terjadi proses sosial yang saling bertukar, dimana sosiokultural yang ada memberi kontribusi pada usaha yang ada dan sebaliknya logika bisnis dengan kalkulasi ekonomi yaitu efisiensi dan efektivitas dalam penggunaan sumber daya baik alam (SDA), tenaga (SDM), modal dan waktu.

Pembahasan penguatan peran modal sosial dalam usaha atau peningkatan ekonomi keluarga tidak lepas dari adanya upaya jalinan kerjasama di antara aktor yang memiliki kesamaan kepentingan. Merunut asal muasal kerjasama berawal dari adanya hubungan kekerabatan yaitu rute utama yang digunakan kepentingan-kepentingan individu 
Jurnal Pemikiran Sosiologi Volume 1 No. 2, 2012

Modal Sosial Perempuan dalam Peran Penguatan Ekonomi Keluarga

Dewi Cahyani Puspitasari

menuju kerjasama sosial adalah seleksi kerabat (kin selection), hubungan ketetanggaan dan resiprositas. Dimensi nilai, kultur, dan persepsi dibangun sebagai pondasi awal untuk mengkolektifkan kesamaan kepentingan dalam wadah institusi berupa komunitas Temu Suruh dan koperasi melalui fasilitasi pendampingan LSM lokal. Dengan demikian, peran modal sosial dalam peningkatan ekonomi keluarga adalah strategis dalam mengatasi kompleksitas masalah yang ada. Solidaritas yang ada mampu memunculkan solusi yang bermanfaat secara kolektif. Selain itu, modal sosial dalam pemahaman untuk kajian pembangunan masyarakat menjadi penting maknanya sebagai acuan analisa untuk aplikasi atas program pembangunan. Hal ini jelas karena dimensi modal sosial dapat mengungkap realitas di masyarakat atas kejadian distrust, melemahnya kohesivitas dan solidaritas, indikasi kemiskinan, dan sebagainya karena terkait dengan kearifan lokal berupa nilai dan budaya masyarakat.

\section{E. Penutup}

Dalam kaitannya upaya peningkatan pembangunan dan kemandirian ekonomi masyarakat ternyata menjadi keharusan untuk ditangani secara holistik khususnya bagi pengambil kebijakan dengan memanfaatkan segala potensi yang ada termasuk potensi modal sosial masyarakat. Hal ini menjadi penting, mengingat aspek pemberdayaan ekonomi keluarga menjadi sebuah entry point untuk memajukan kesejahteraan masyarakat. Implementasi beragam kebijakan dan program yang berorientasi pada pemberdayaan ekonomi keluarga patut diapresiasi dalam perannya memberi peluang akses khususnya perempuan sehingga dapat meningkatkan kualitas penghidupan keluarga. Dengan demikian,pemberdayaanmasyarakat dengan melibatkan dimensi kultural dan mendayagunakan peran modal sosial yang ada di tengah masyarakat dapat mengoptimalkan hasil dari proses pemberdayaan.

Modal sosial perempuan memiliki komponen yang berisikan trust, nilai dan norma sosial, resiprositas yang menjadi pondasi dalam mekanisme dan membentuk institusi kerjasama dapat dimanfaatkan untuk penguatan ekonomi keluarga. Keterbatasan finansial mampu disiasati oleh perempuan dengan memanfaatkan peluang jejaring sosial berupa arisan, forum pengajian dan koperasi dengan basis kepercayaan satu sama lain. Kondisi ini menjadikan akses terhadap sumber daya ekonomi bagi perempuan semakin terbuka yang sepenuhnya mengandalkan hubungan baik sehingga ekonomi keluarganya mampu bertahan (survive) dan ada yang mengalami peningkatan. Dengan demikian, posisi perempuan sebagai pengelola keuangan keluarga ditegaskan dari serangkaian usaha produktifnya yang secara strategis memanfaatkan potensi modal sosial di lingkungan sosial-kemasyarakatan.

\section{Daftar Pustaka}

Dasgupta, Partha dan Ismail Seralgedin. 2000. Social Capital-A Multifaceted Perspective, Washington, DC:World Bank

Fukuyama Francis.2002.The Great Disruption: Hakikat Manusia dan Rekonstitusi Tatanan Sosial. Yogyakarta:CV Qalam.

Hermawanti, Mefi dan Hesti Rinandari. 2003. Local Empowerment Module in Indonesia.Yogyakarta: IRE dan European Initiative For Democracy and Human Right.

Ihromi,TO (ed). 2004. Bunga Rampai Sosiologi Keluarga.Jakarta: Yayasan Obor Indonesia.

Hasbullah, Jousairi.2006.Modal Sosial (Menuju Kebudayaan Indonesia), Jakarta: MRUnited Press.

Mustar Ediastuti, Endang. 2007. Sumber Daya Manusia 
Jurnal Pemikiran Sosiologi Volume 1 No. 2, 2012

Modal Sosial Perempuan dalam Peran Penguatan Ekonomi Keluarga

Dewi Cahyani Puspitasari

Indonesia.Yogyakarta:Jurnal Populasi volume 18 nomor 2 tahun 2007.

Mafruhah, Izza. 2009. Multidimensi Kemiskinan. Surakarta: Sebelas Maret University Press.

Agus, Herliawati. 2009. Pemberdayaan Ekonomi Perempuan dan Pengembangan Modal Sosial. Jakarta: FISIP UI.

Puspitasari, Dewi Cahyani, dkk.2009. Modul Pembelajaran Untuk Perempuan Usaha Mikro: Refleksi Pengalaman Pendampingan Kelompok Temu Suruh Daya Annisa.Yogyakarta: Daya Annisa dan Central Java Community Assistance Program An Australian Government Initiative.

Puspitasari, Dewi Cahyani.2010. Paper berjudul : Konfigurasi Modal Sosial Pasca Bencana di Yogyakarta : Studi Kasus Program Pemulihan Bencana Dompet Dhuafa Republika, dalam ICSBE (International Conference on Sustainable Built Environment).

Prasetyantoko,dkk (ed). 2012. Pembangunan Inklusif: Prospek dan Tantangan Indonesia. Jakarta: LP3ES dan PRAKARSA. 